\title{
COMMENT ON PETERSON AND SELVIN
}

\author{
Lea Brilmayer*
}

Mark Peterson's and Molly Selvin's interesting article, Mass Justice: The Limited and Unlimited Power of Courts, ${ }^{1}$ deals with the role of courts as participants in the resolution of mass tort cases. Peterson and Selvin claim, in particular, that courts have interests in aggregating litigation, in part because judges wish to reduce the boredom and the imposition on their calendars that they would face if forced to adjudicate individually large numbers of similar claims such as those involving asbestos and Bendectin. "Faced with mass tort litigation," they write, "judges are not simply neutral arbiters; rather, they have strong personal incentives to speed the judicial process, save costs and labor, and reduce redundancy."'2 There is an obvious logic to their analysis, and the topic they have chosen is important and well deserving of their attention. Here, I wish merely to note a few reservations about this article with which I, on the whole, largely agree. My reservations stem from my suspicion that the issue of judicial interest in aggregation is a bit more complicated than Peterson and Selvin let on.

First, generalizing about judges may be as treacherous as generalizing about the parties to the litigation. Peterson and Selvin are aware, of course, that not all plaintiffs think alike, and neither do all defendants. ${ }^{3}$ There may be situations in which delay is advantageous to a defendant, but in other situations it may be the plaintiff who profits from postponing resolution. It all depends on the circumstances of the particular case. What is true of delay is also true of aggregation: it all depends on the circumstances. Sometimes defendants favor aggregation, and sometimes they oppose it. One might expect that it would be the same with judges. Yet the article does not address how judges' preferences might depend on the circumstances, sometimes seeming to assume instead that judges invariably prefer aggregation. ${ }^{4}$

Naturally enough, this is not the case. I know of at least one instance in which a trial judge actively attempted to disaggregate a large case into its component parts. The case was a dispute over insurance coverage of toxic

Copyright (c) 1991 by Law and Contemporary Problems

* Nathan Baker Professor, Yale Law School.

1. Mark A. Peterson \& Molly Selvin, Mass Justice: The Limited and Unlimited Power of Courts, $54 \mathrm{~L}$ \& Contemp Probs 227 (Summer 1991).

2. Id at 230.

3. See, for example, id at 232 (parties and their lawyers "do not always" share interests in aggregation); id at 232-33 (describing interests that different plaintiffs and defendants sometimes have).

4. See, for example, id at 233 (courts almost always have the strongest interest in aggregation). 
discharge occurring at many sites around the country. ${ }^{5}$ The judge used the forum non conveniens doctrine to disaggregate the case, claiming that sitespecific inquiries were needed at each of the toxic waste disposal sites. ${ }^{6}$ Of course, one might argue that insurance coverage disputes are quite different from products liability cases, and it is possible that the differences are substantial enough that they should be treated differently. I do not know. One might also argue that a few instances of this sort do not disprove the existence of a general trend toward increased aggregation (a trend that may, for all I know, exist).

Even if true, however, these arguments do not undercut my basic point. Judges do not all react in the same way when faced with mass tort cases. It is possible that this has something to do with particular personalities; some judges, perhaps, have more highly developed tastes for management of mass litigation. It would be worth knowing what factors account for the willingness to aggregate in some cases but not others. Even if there is a trend toward greater aggregation, all large scale cases are probably not brought together this way. Which?, why?, and when? are all appropriate questions to ask.

A second complication deals with the reasons that Peterson and Selvin suggest for the judicial inclination to aggregate. They write that "judges almost always have the strongest interest in resolving mass litigation through the use of aggregative procedures. Grouping serves the personal interests of judges in conserving their time and labor and in minimizing uninteresting, repetitive proceedings." 7 While this is not the only reason they offer, it is one they mention several times. ${ }^{8}$ Given that judges, like other people, are naturally inclined to minimize unnecessary work and tedium, how can this be consistent with examples such as the one I mentioned just above where a trial judge actually disaggregated a case?

The answer is pretty obvious. Even if that judge was motivated by a desire to reduce his or her workload (a point on which I express no opinion), this goal would be better served by disaggregation than by aggregation. If the case is disaggregated, then large portions of it will have to be heard by other judges. Indeed, Peterson's and Selvin's reasoning about avoiding repetition and tedium only makes sense if one assumes that the same judge-the one deciding the aggregation issue-will also adjudicate the cases if they are litigated singly. If a judge has a choice between trying one hundred drug liability cases in series, and trying them in a single, combined proceeding, then the desire to avoid repetition will very likely motivate the judge to combine the cases. But the more likely choice is between trying one case and

5. Westinghouse Electric Corp. v Aetna Casualty E' Surety Co., 227 NJ Super 504, 547 A2d 1167 (1988), rev'd sub nom Westinghouse Elec. Corp. v Liberty Mutual Ins. Co., 233 NJ Super 463, 559 A2d 435 (1989).

6. $227 \mathrm{NJ}$ Super at 508-10, 547 A2d at 1169-70. On this issue, see generally Peter J. Kalis \& Thomas M. Reiter, Forum Non Conveniens: A Case Management Tool for Comprehensive Environmental Insurance Coverage Actions?, 92 W Va L Rev 391 (1989).

7. Peterson \& Selvin, 54 L \& Contemp Probs at 233 (cited in note 1).

8. See also id at 230-32. 
trying a hundred cases combined into a single proceeding. Other judges will probably hear the other ninety-nine. Desire to minimize repetition and tedium cannot explain why some judges reach out to take on cases that they otherwise would not have to hear at all.

Indeed, if avoiding boredom were the predominant explanation, then we would have a serious collective action problem here. Aggregation does not always promote efficiency, but surely it does sometimes; when it does, the judicial system as a whole would benefit from aggregation. In terms of purely personal interest, however, judges trying to avoid boredom or unnecessary work would have no motivation to take on the extra problems of aggregating. Thus, following this narrowly defined and purely personal interest would be disadvantageous to the collective interest. We know that sometimes aggregation does occur, of course, so there must be other motivations at work. The apparent willingness to aggregate suggests that judges are probably acting out of some sense of duty toward the judicial system as a whole (although it is also possible that some judges enjoy managing big cases). At any rate, the motives are varied and sometimes unclear; the explanation cannot be as simple as Peterson and Selvin suggest.

This suggests a third question. When Peterson and Selvin talk about "the interests of judges," do they mean the interests of judges or the interests of the judicial system as a whole? As the remark about collective action problems suggests, what is in the interests of the judicial system as a whole (for instance, efficient dispute resolution) is not necessarily in the interest of any particular judge; conversely, if each judge follows his or her own best interest, the overall interests of the judicial system may not be served. Which of these-the collective or the individual interest-is the one that really matters? From a policy point of view, we might not particularly care whether the personal interests of judges were furthered. What we might really want to further is the effective functioning of the system of dispute resolution. Of course, in order to make the system as a whole function well, we ought to understand the incentives of individual judges. We would want to structure their incentives in such a way as to minimize the possibility that their selfinterest would conflict with the needs of the system. But it will not do simply to treat the interests of judges and the interests of the judicial system as interchangeable, for sometimes they coincide and sometimes they do not.

Finally, it is worth investigating independently the normative questions raised by the fact that judges have interests in whether cases are aggregated. I realize that Peterson and Selvin do not take on this question, focusing primarily on description of the incentives that judges actually face. But we ought also to ask whether we care about judges' preferences. Strategically, of course, we care for the reason already mentioned: we want to minimize the likelihood that judges' interests will collide with the needs of the court system and of society. This is not to say, however, that we think that judges are entitled to have their preferences taken into account, and that the dispute 
resolution system ought (in the normative, as opposed to the strategic, sense) to reflect their wishes.

Judges, after all, are not like litigants. The judicial system is set up to be responsive to the needs of the litigants, or at least to their legitimate needs. Litigants are entitled to have personal preferences about issues like delay, settlement, and aggregation. Is it the same with judges? Are judges entitled to have a preference for reducing boredom? Or do we prefer to think of judges as fiduciaries, so to speak-as acting solely as agents for the parties and society, bound to further the interests of others?

I do not know the answer to this question, any more than I know the answers to the other questions that I have raised about Peterson's and Selvin's article. But these are questions worth posing about the role of judges in mass tort litigation, and I am grateful for this opportunity to ask them. 